\title{
Domestic experience in organization of mobile construction
}

\author{
Pavel Oleinik* \\ Moscow State University of Civil Engineering, 26 Yaroslavskoye Shosse, 129377, Mos- \\ cow, Russia
}

\begin{abstract}
The stages of formation of the mechanism of mobile construction and its role in solving major economic problems are considered. The article analyzes the effectiveness of mobile units in agricultural and water management, transport construction. The author emphasizes a fundamentally new approach to mobile construction using the complete-block method of construction of buildings and structures. As an example, the author reveals the experience of construction of the Astrakhan gas processing plant, which illustrates the synthesis of mobile methods of work organization and industrial space-planning solutions in the form of large blocks of technological equipment devices and installations. At the same time, specific engineering solutions for the preparatory period of construction, characteristics and composition of the residential settlement built in the process of pioneer development of the territory are given.
\end{abstract}

\section{Introduction}

The mechanism of mobile construction of buildings and structures began to actively form in the $60-70$ s of the twentieth century. It was in these and subsequent years that major national economic tasks of intensive development of the country's economy were solved through the creation of powerful territorial-production and fuel-energy complexes. For example, during the tenth five-year plan (1976-1980), more than 1200 industrial enterprises were put into operation, and more than 530 million $\mathrm{m}^{2}$ of living space were commissioned. In particular, due to the high activity of the construction industry in collaboration with other industries, the West Siberian oil and gas complex was developed at the Urengoyskoye, Zapolyarnoye and Medvezhye fields, power units were launched at the Surgutskaya and Urengoyskayaregional hydroelectric power plants, as well as hydroelectric units at Bratskaya, Krasnoyarskaya, Sayanst-Shushenskaya, UrengoyIlimskaya HPP, the Baikal-Amur and South Siberian mains were built, the Urengoy-Chelyabinsk and Urengoy-Center gas pipeline systems, the Surgut-Polotsk oil pipeline with a total length of over 50 thousand km, gas processing plants with a total capacity of 16.5 billion $\mathrm{m}^{3}$ of gas per year were put into operation, etc. [1].

\footnotetext{
*Corresponding author:aljurgaitis@gmail.com
} 


\section{Materials and Methods}

It should be noted that in almost all types of the construction industry, mobility was the most important factor in increasing the efficiency of construction production [2]. Mobile formations were used not only for the construction of new enterprises, buildings and structures, but also for removing peak loads, especially at start-up construction sites. So, for example, for agricultural and water management construction, starting from 1963, in the system of the Ministry of Construction of the RSFSR, mobile mechanized columns (MMC) were created - maneuverable subdivisions of construction and installation enterprises for performing construction and installation work on scattered and linear objects. The first MMCs were organized in the Omsktselinstroy and Altaitselinstroy trusts. For mechanized columns, the annual volume of work under the general contract was set from 2.0 to 2.5 million rubles. In Omsktselinstroy, the Olginskaya mechanized column consisted of three mobile units, each of which included three integrated brigades with 60 workers of various specialties. The volume of work performed by them, for example, in 1964, amounted to 1,700 thousand rubles. At the same time, on the whole, for the Omsktselinstroy trust, output per worker in mechanized units amounted to 4450 rubles against 3684 rubles of average annual output by enterprises of the Ministry. As a rule, such mechanized columns were tied to certain regional centers, in which their production bases and housing stock for workers were located. The workers were transported to the place of work by road. The maximum radius of the location of objects was no more than $60 \mathrm{~km}$.

In water management construction, mobile mechanized columns carried out the construction of irrigation and drainage systems 6 and maintenance of the operated melioration systems and structures. In conjunction with the construction of these facilities, work was also carried out on land cultivation, liming of acidic soils, pre-sowing cultivation, fencing pastures along the outer contour, etc. The scope of maintenance work included the entire complex of repair activities related to maintenance, repair and overhaul of the irrigation and drainage network, its hydraulic structures. The MMC, together with the construction sites of the maintenance and repair departments "Rosvodstroy", were the main organizational forms both at the district and inter-district levels.

The unique experience of mobile construction has been accumulated in transport construction - in railroad transport, main pipeline transport, construction of bridges and tunnels. The organization of construction on the railway is very complicated, since on vast and, as a rule, underdeveloped territories, various objects are erected according to a single scheme railways, tunnels, bridges, buildings, etc. In this regard, the construction complex involves diversified large mobile construction subdivisions - specialized departments, construction companies, construction and assembly trains, bridge brigades. The formation of an effective management system is the most important task on the railway in view of the specific features - the scattering of divisions along the route, the presence of undeveloped territory and off-road, the need for high-quality coordination in time and space of production and transport processes, difficulties in the logistics to construction sites. In addition, the technological and structural diversity of railway construction projects dictates the mandatory cooperation of a number of construction organizations to achieve the necessary synchronization of production processes. But at the same time, the nomenclature of complex and object flows is clearly distinguished. For example, the object flows are the construction of the roadbed by the forces of mechanized columns, the construction of artificial structures (bridges, tunnels, overpasses, etc.) by bridge-building teams, the construction of the upper structure of the railway track using construction and assembly trains (Fig. 1). 


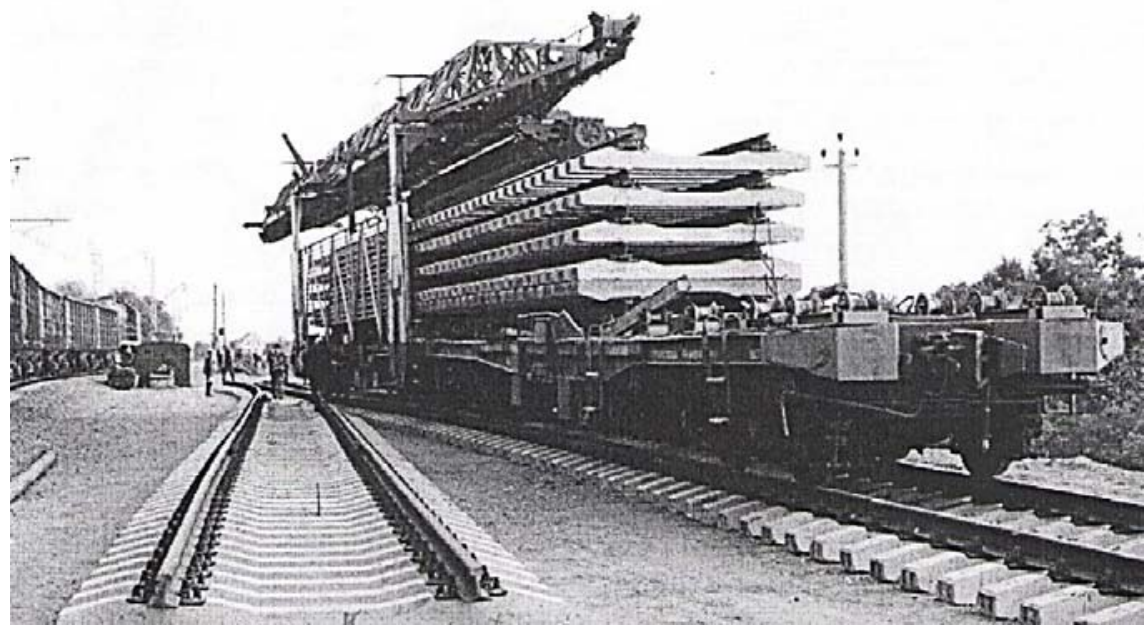

Fig. 1. Construction of the upper structure of the railway track

These mobile structures, as separate contracting and subcontracting divisions, carry out work in accordance with the work projects developed by them, which are synchronized with the project for organizing a complex of works for the entire construction period, developed by the general contracting construction organization. This approach allows taking into account the most important feature of the construction of railway tracks - a constant change in the conditions of work and the nature of linear-extended objects [3, 4].

Mobile formations for laying main pipelines are distinguished by extremely high mobility $[5,6]$. Usually, for pipes with a diameter of up to $500 \mathrm{~mm}$, low-alloy steel is used, and for large-diameter pipes of 1000-1420 mm, low-alloy steel grades are used with obligatory heat treatment for strengthening and rigidity. Such pipes are made with a length of 11.6 meters using seamless technology or with an electric welded seam. Various polymers and polyethylene are used for pipe insulation. Pipes are laid in trenches using specialized heavy equipment (Fig. 2).

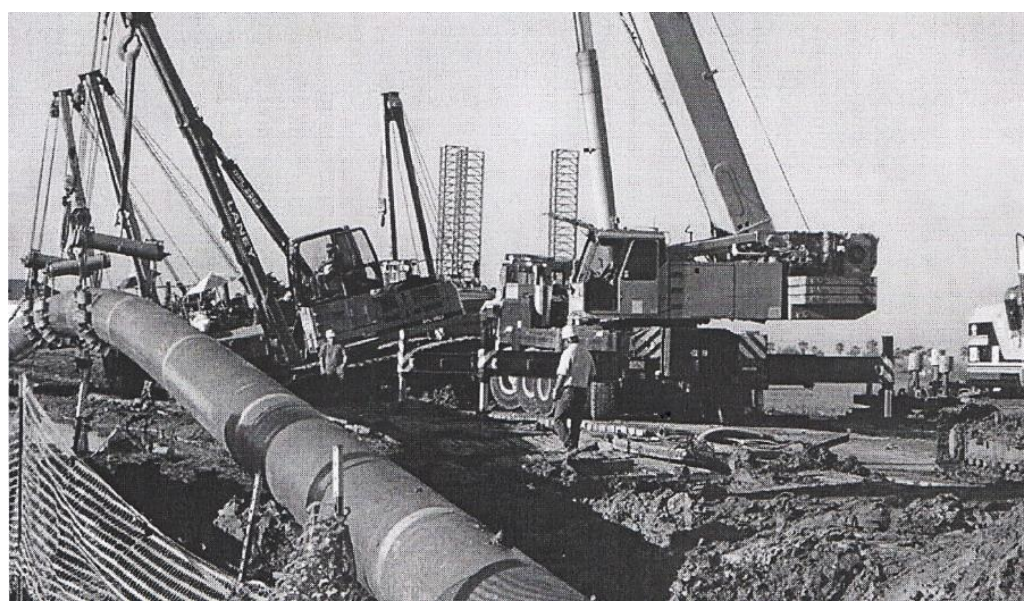

Fig. 2. Laying the main pipeline 
Huge and rich experience has been accumulated in the construction of large-scale hydroelectric power plants. But at the same time, the long construction time of such unique complexes is forcing the construction of a permanent housing stock and all the corresponding infrastructure for permanent residence of first the builders with their families, and then the operating personnel. Therefore, for the construction of such structures, as a rule, by order of the Ministry of Construction of Power Plants of the USSR, specialized construction and installation departments were formed,whichcore workers were professional builders from other usually completed construction projects. An example is the experience of building the Krasnoyarsk hydroelectric power station on the Yenisei River near the town of Divnogorsk. This hydroelectric station is the second in terms of capacity after the SayanoShushenskaya hydroelectric power station in Russia and is one of the ten largest in the world. In 1955, by order of the Ministry of Construction of Power Plants of the USSR, a specialized construction and installation department for the construction "KrasnoyarskGESstroy" was created, and already in 1956, they began to carry out preparatory work - the construction of residential buildings, roads, a construction base, etc. The first hydroelectric unit of the Krasnoyarsk HPP was launched in November 1967, and the last - in December 1971. The scale of such structures should be noted. During the construction, 9.45 million $\mathrm{m}^{3}$ of soft soils were processed, 6.4 million $\mathrm{m}^{3}$ of rock was extracted, 5.8 million $\mathrm{m}^{3}$ of concrete and reinforced concrete were laid, 118 thousand tons of metal structures, mechanisms and equipment were installed [7].

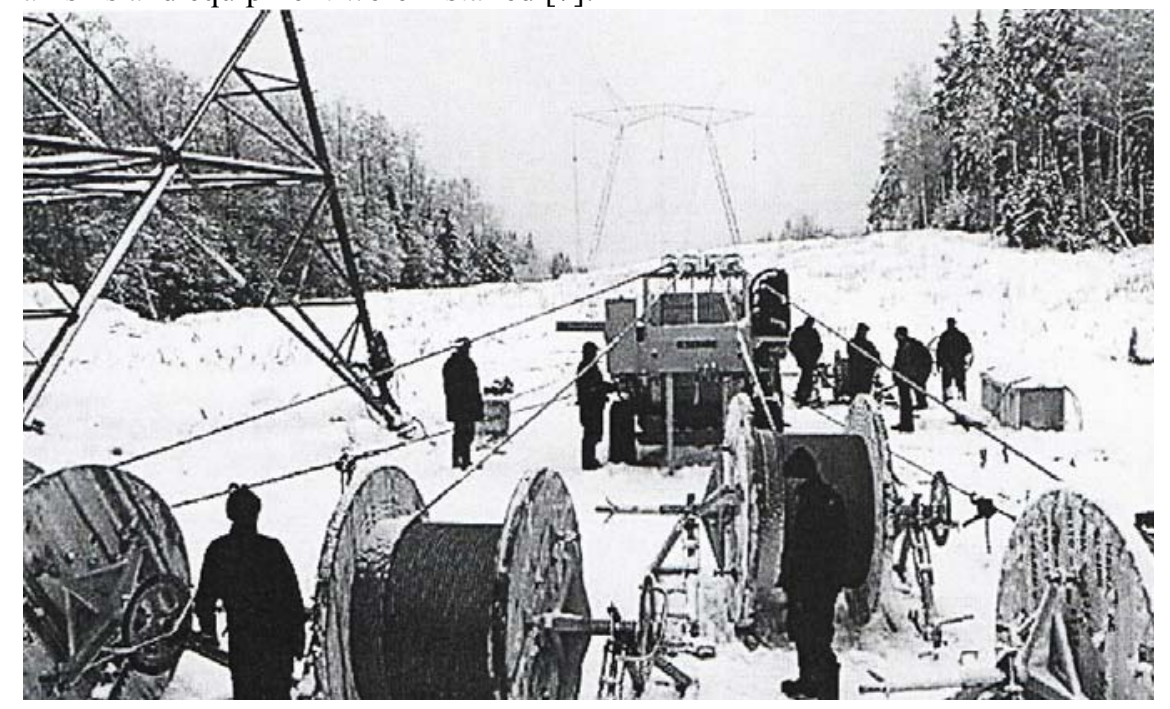

Fig. 3. Pulling of wires of overhead lines

Mobile formations are actively and successfully working in the basic industry of the Russian economy - the electric power industry (Fig. 3). For example, in the 80s of the twentieth century, the construction of a power transmission line $750 \mathrm{kV}$ became widespread. By this time, such voltage classes as $1150 \mathrm{kV}$ AC and $1500 \mathrm{kV}$ DC did not exist in the world.Therefore, the construction of transmission lines of such a high voltage opened up great prospects for our country, since it became possible to transfer electricity over thousands of kilometers with minimal losses. The goal was set to create a unified energy system of the Soviet Union from five subsystems of Siberia, Kazakhstan, Ural, Volga and Center. The Siberia - Kazakhstan - Ural branch was built and put into operation in stages. The Resolution No. 243 "On the creation of the Ekibastuz fuel and energy complex and the con- 
struction of a $1500 \mathrm{kV}$ DC power transmission line Ekibastuz - Center" was adopted. The construction of large thermal power plants on huge coal reserves made it possible to provide electricity not only to Kazakhstan, but also to other regions. For this, a decision was also made to build $500 \mathrm{kV}$ power lines and a unique $1150 \mathrm{kV}$ AC transmission line Ekibastuz - Ural with a length of $900 \mathrm{~km}$ with substations in Ekibastuz, Kokchetav, Kustanai and the Kustanai - Chelyabinsk section of $300 \mathrm{~km}$.

The general contractor for the construction of the power transmission line VN-1150 kV was the Spetssetstroy trust. For the construction of facilities at the Ekibastuzskaya substation $1150 \mathrm{kV}$ - the Ekibastuzenergostroy trust. For the construction of substations in Kokchetav, Kustanai and Chelyabinsk - the Yuzhuralenergostroy trust.

The construction of the $1150 \mathrm{kV}$ overhead line was carried out by several mobile mechanical columns and was ahead of the construction of substations. The construction of the first of the four substations was started by the general contractor - SUEPK. To increase industrialization and reduce construction time, design institutes have adopted improved designs with the assembly of individual units at assembly sites.

The existing practice of substation construction at the facilities of the $1150 \mathrm{kV}$ substation was unacceptable, since the oil-filled electrical equipment mounted on the site weighed more than 500 tons. The metal structures of linear and cell portals weighed up to 30 tons and were mounted at a height of 40 meters or more with significant dimensions.

At that time, the contractors used advanced mobile lifting equipment for their installation - Kato, Dnepr, Yanvarets, and DEK-50 cranes, Magirus-Bronto-33 and AGP-22 aerial platforms, etc. Using the above equipment in the space-limitedarea of the site, builders and installers had to show ingenuity to organize the trouble-free operation of mechanisms. With a large concentration of mechanisms at the construction sites, a ring scheme of temporary power supply was successfully applied, which excludes disconnection and damage to lines when moving mechanisms.

To coordinate the aforementioned activities in Ekibastuz, the working design group of the Odessa branch of the Orgenergostroy Institute worked, which developed projects for the production of work and technological processes for the installation of building structures and equipment.

In the last days of 1985, for the first time in world practice, voltage was applied to the unique equipment of the Ekibastuz $1150 \mathrm{kV}$ substation.

The development of new areas, the constantly increasing volume of work on the construction of oil and gas pipelines, power transmission lines, roads and railways has put forward a significant increase in the mobility of construction organizations as one of the most pressing problems.

Practice has shown that traditional forms of construction of facilities with the help of stationary construction companies are not acceptable, since their workers live with their families in the immediate vicinity of the construction site and, after completion of work, move to new facilities in the same region.

A fundamentally new approach to the activities of mobile units was developed with the creation of the fuel and energy complex of Western Siberia, which has become the main one in the country's economy.

Its intensive development is directly related to the emergence of a complete-block method for the construction of oil and gas industry facilities. The vast territory of the Tyumen region is characterized by harsh climatic and difficult geological conditions - the presence of permafrost soils, high waterlogging, large fluctuations in the level of groundwater, etc. In general, most of the region's territory is classified as underdeveloped, and its regions of the Far North are notable for inaccessibility. At the same time, for the development of the region, it was necessary to quickly create normal housing, communal and social condi- 
tions. In addition, the high scattering of construction over a vast territory required a large amount of linear construction - roads and railways, power lines, trunk pipelines, etc.

In the above conditions, it is completely pointless to build both stationary objects themselves and to apply traditional methods of construction. A new technical basis for industrial construction was needed. As a result, three areas for the development of fixed assets were outlined:

creation on the basis of typification and unification of technological processes of flow lines for assembling blocks, units and structures with partial or full automation of production processes;

maximum transfer of the volume of construction and installation work from the construction site to the sphere of industrial enterprises by aggregating material resources into blocks and units;

formation of special assembly and transport-assembly equipment for the complete provision of the work of the production lines of the construction conveyor.

To implement these areas in Western Siberia, a production system was created, consisting of: SibNIPIgazstroy - research and development and design of facilities in a completeblock design; Sibkomplektmontazh association - production, delivery to the construction site, installation of complete block devices; general contracting trusts leading the pioneering development, preparation and engineering support of construction sites. Here we mean that the main organizational form of the complete-block construction method is a mobile construction and installation enterprise, which ensures the assembly, manufacture and transportation of block devices to the construction site, their installation and commissioning of objects.

Thus, the new approach consisted in the system of mobility of construction and assembly structures, providing them with block devices of various functional purposes $[1,8,9]$.

\section{Results and Discussion}

The analysis showed that the duration of the construction of objects in this case is reduced by one to two years, and on a number of objects by 2-3 times with a decrease in labor costs at the construction site in 13.5-24 man-year by 1 million rubles of construction and installation works. For example, during the construction of integrated gas treatment units at the Urengoyskoye gas field, the volume of construction was reduced by $32 \%$ due to the compact arrangement of equipment, and the building area of technological buildings was reduced by $37 \%$. At the same time, the consumption of steel was reduced by $29 \%$ [1]. The country had a wide network of assembly enterprises in the Komi Autonomous Soviet Socialist Republic, Tatarstan, Bashkiria, the Moscow Region, Orenburg and other regions [10]. The development of the oil and gas industry necessitated the creation of units in the Ministry of Oil and Gas Construction, specializing in the manufacture, transportation and installation of block devices - the Tatkomplektmontazh trusts, Spetsstroymontazh, Centerkomplektmontazh, etc. According to the Central Statistical Administration of the USSR, in the eleventh five-year period, the construction ministries carried out 5.05 billion rubles of construction and installation works, including

$$
\begin{array}{ll}
1981-0.68 \text { bln. rubles } & 1984-1.14 \text { bln. rubles } \\
1982-0.86 \text { bln. rubles } & 1985-1.34 \text { bln. rubles }
\end{array}
$$

$1983-1.03$ bln. rubles

The construction of industrial enterprises by mobile formations using the completeblock method (CBM) has its own specific features $[11,12,13]$, and in this regard, the ad- 
vanced experience of construction and installation enterprises of the All-Union Construction and Installation Association Soyuzspetspromstroy of the USSR Ministry of Industry and Construction and the Neftekhimmontazh trust of the USSR Ministry of Mounting and Construction on the construction of the 1st stage of the Astrakhan gas processing plant deserves attention [14].

The complex of a gas processing plant with a processing capacity of 6 billion $\mathrm{m}^{3}$ of gas condensate per year, in accordance with the current regulatory documents in construction, belongs to the category of particularly complex facilities and has no analogues in terms of productivity among similar enterprises of Mingazprom.

The plant complex included more than 30 technological units, and the total number of buildings and structures exceeded 400 units. Installation of technological equipment blocks and communication blocks was carried out in the production area of the plant.

The production area of $820 \times 540 \mathrm{~m}$ occupied the central part of the industrial site of the plant. It included the facilities for processing gas, gas condensate and sulfur production. The production area was divided into separate quarters, which were connected by overpasses for pipelines and electric cables and a network of roads. The YuzhNIIGiprogaz project provided for the possibility of expanding the production area of the plant in the future.

In preparation for the installation of technological equipment blocks, a significant amount of off-site preparatory work was performed:

construction of a berth for river vessels on the Buzan river;

construction of an asphalt-concrete road from the berth to the plant site;

construction of a production base for the repair and maintenance of Faun HZ 40.45/46 vehicles, Nicholas R 12/2 trailers.

The high building density of the territory of the production zone (about 70\%), the complex layout and placement of technological setups and foundations with external technological equipment made increased demands on the organization and technology of production of on-site preparatory work. In total, 94 blocks of technological equipment with a total weight of 12 thousand tons were mounted. The maximum weight of a block located horizontally was 254 tons, and that mounted vertically - 420 tons. Horizontal apparatuses were mounted on spring supports, which were installed on roller supports, 32 large-sized blocks were assembled on an assembly site. More than 20 blocks were pre-lined with refractories, and a metallized coating was applied to 12 units. The installation of technological equipment blocks was carried out by a crawler crane with a lifting capacity of 500 tons and a pneumatic-wheeled crane with a lifting capacity of 300 tons. These circumstances required the advance arrangement of widening of permanent roads, an increase in their radii of curvature from 12 to $40 \mathrm{~m}$, as well as the construction of installation and assembly sites at the places of installation of equipment blocks.

In the preparatory period, a vertical leveling was performed in the amount of 180 thousand $\mathrm{m}^{3}$ of sandy soil, $21 \mathrm{~km}$ of underground interunit communications were laid, 40 thousand $\mathrm{m}^{2}$ of permanent interunit roads were made of monolithic concrete, 600 foundations on piles from interunit overpasses were made. In addition to this, there were built:

warehousing and pre-assembly areas for technological equipment units and the passage of vehicles with an area of 42.8 thousand $\mathrm{m}^{2}$;

platforms with an area of 16.5 thousand $\mathrm{m}^{2}$ for the operation of the Demag SS-4000 crane with a lifting capacity of 500 tons;

roads for the relocation of the SS-4000 crawler crane with an area of 2.7 thousand $\mathrm{m}^{2}$. Temporary roads and platforms are made of PAG-14 prefabricated slabs.

Mobile buildings for auxiliary purposes were interlocked into a complex of household townships and mounted outside the production area of the plant.

At the next step, the following works were performed at each unit: 
excavation of pits for all foundations of buildings and structures;

driving piles under the foundations of all buildings, structures and foundations of blocks of external technological equipment;

installation of pile grillages for foundations and building foundations for buildings, independent stack-frames, overpasses;

adding soil for the laying of intra-unit underground networks of water supply, sewerage, electric cables, communication cables, lightning protection bands, etc.;

laying of underground engineering networks;

backfilling of foundation pits and hollows with local soil with compaction;

construction of permanent intra-unit passages and temporary sites for the installation of blocks of heavy-weight technological equipment and communication blocks.

A fundamentally new solution to the organization of construction was the proposed integrated technology for the production of work on driving piles, installing concrete grillages and foundations, laying underground engineering and transport communications throughout the open area. This solution made it possible to make foundations for all buildings, independent stack-frames, overpasses, blocks of technological equipment, lay underground pipelines, lightning protection strips, build intra-unit roads and sites at the earliest stage of construction of the unit, ensuring the start of work on the installation of blocks of largesized heavy equipment at the beginning of the main period construction.

In the process of pioneering development of the construction site, housing settlements (complexes) and production bases from mobile inventory buildings were erected [15].

The housing complex for 4 thousand inhabitants was built from mobile buildings of collapsible type at the Aksaraysk station, Astrakhan region for the builders of the Astrakhan gas processing plant. The housing complex consisted of three-storey residential buildings with one-, two- and three-room apartments, hostels. To serve the builders and their families, shops, canteen, nursery-kindergarten, school, hospital, club, consumer services complex, bathhouse, laundry and dry-cleaner, communications center, television studio, pharmacy, and sports complex were built. In addition, the complex was serviced by a boiler room, a power plant, a fire station, water supply and sewerage treatment facilities. Also, two hotels, the village Council of People's Deputies and the administrative building of the industrial construction and assembly association "Astrakhanpromgazstroy" were located in the housing complex.

Prior to the installation of mobile buildings, the engineering preparation of the construction site of the residential complex was carried out, including:

bank protection works with paving of the Akhtubariver embankments with reinforced concrete slabs PAG-14 and monolithic concrete;

laying of underground water supply, sewerage, heating systems;

building passages made of monolithic concrete.

\section{Conclusions}

The use of rotational, expeditionary and rotational-expeditionary methods of organizing work requires solving the following problems:

- significant development of rear support bases capable of providing mobile units with the necessary material resources;

- development of fundamentally new and improvement of existing design solutions with minimal labor costs at the construction site;

- the use of stimulating factors to increase the mobility of workers in construction companies working on mobile methods of organizing work; 
- increasing the versatility and mobility of construction equipment and mobile bases of the construction industry;

- development of projects for rotational (expeditionary) camps based on the use of mobile inventory buildings with a set of solutions for social, household and medical services for employees;

- provision of mobile construction companies with mobile inventory buildings of container and collapsible types of production, warehouse, auxiliary, residential and public purposes.

\section{References}

1. V. G. Andrienko et al. Industrialization of construction of oil and gas industry facilities (Nedra, Moscow, 1985)

2. S. Ya. Kurits,Block-complete construction in the oil and gas industry (Nedra, Moscow, 1977)

3. V. D. Shapiro, Page of pipelines 11, 9-11 (1981)

4. A.V. Matveev, Bulletin of construction equipment 8, 10-12 (1996)

5. A. Zheltenkov et. al. IOP Conference Series: Earth and Environmental Science 90(1), 012122 (2017)

6. T. A.Verminskaya, Almanac of modern Science and Education 7, 37-39 (2008)

7. P.Oleynik, Industrial and civil construction 6, 46-50 (2019)

8. Yu. N.Permikin et al., Experience of construction of objects by the complete-block method and problems of its further development: review (Moscow, VNIIIS, 1988)

9. E. A.Shepeleva, A. L. Shepelev, Organization of construction of production facilities by the complete-block method (CPI SAFU, Arkhangelsk, 2013)

10. P.Oleynik, Organization of construction production (ASV Publishing house, Moscow, 2010)

11. P. Oleynik,I.V. Stepanov, Mobile buildings in construction(Stroizdat, Moscow, 1985) 